Rev. Biol. Trop. 52(1): 115-118, 2004

www.ucr.ac.cr www.ots.ac.cr www.ots.duke.edu

COMMUNICATION

\title{
Are there any agricultural effects on the capture rates of male euglossine bees (Apidae: Euglossini)?
}

Juan Carlos Sandino

Fundación Herencia Verde, Cali, Colombia. Present address: Facultad de Biología Marina, Universidad Jorge Tadeo Lozano, Carrera 4 22-61, Bogotá, Colombia; juancarlos_sandino@ hotmail.com

Received 13-XII-2001. C Corrected 21-VIII-2003. Accepted 04-IX-2003.

\begin{abstract}
During 30 days male euglossine bees were bait-sampled at 12 sites, in the central Pacific coast of Colombia (ten days and four sites at each of three adjacent habitats: farmlands, highly disturbed forest and less disturbed forest) and 487 individuals were captured. Most captured individuals belonged to six species, five widely distributed through the American tropics and an endemic species. Two of the frequently captured species presented no different abundances between habitats, while the other four (67.97\% of all the captured individuals), all of them big sized or long-tongued, were more frequently captured at the farmlands. A cluster analysis of the data matrix for the 23 captured species and the 12 sampling sites, grouped together the farmland sites, apart from the forest sites. It is proposed that male euglossine bees from generalist, long-tongued or big sized species, forage frequently at the farmlands, where fragrance or nectar resources may be clumped, less diverse, and present an access restricted by deep corollas or by microclimatic conditions of high temperature and low humidity.
\end{abstract}

Key words: Euglossine bees, Colombia, deforestation gradient, pollinators, farmlands.

During April and May 1995 male euglossine bees were sampled to assess their possible heterogeneous distribution across three distinct and adjacent habitats, on the plains and lower slopes of the central Chocó biogeographic region. Rather than fragmented or any embedded in another, each of the sampled habitats is part of large land strips in a large-scale mosaic. The sampled habitats were: (1) a typical diversified farmland along the riverbanks of the Anchicayá river (Buenaventura, Colombia), (2) a frequently logged forest beside the unpaved road that goes along the river, and farther apart from the road, (3) a forest selectively logged until 15 years before this study.

Along trails within each habitat, four sampling sites were established by placing trap sets every $200 \mathrm{~m}$, a distance at which independent samples have been previously reported (Armbruster 1993). Trap sets at each site, consisted of three non-lethal traps, respective- ly baited with cineol, methyl salicilate and skatol. The homemade traps had the bait at the bottom part, hanging under an inverted funnel (Fig. 1) and thus allowing low dispersion of the chemical odor, though proving effectiveness in capturing approaching male euglossines (Sandino 1995). The traps remained installed 4 hours from 0800/0830 to $1200 / 1230$ and were checked, on average, every $30 \mathrm{~min}$. Male euglossines were identified on the site; dubious specimens and vouchers were collected and deposited at the Museo de Entomología, Universidad del Valle, Cali, and the Laboratorio de Abejas, Universidad Nacional, Bogotá. After identification, the bees were wing-marked with indelible ink of a color specific for each habitat. Alternating sampling dates between habitats and avoiding rainy mornings, ten sampling dates were completed at each habitat. Forewing and folded proboscis lengths from vouchers (Kimsey 1982) were 
used as measurements for classifying the species as either big or small (big $>1.2 \mathrm{~cm}$ forewing length $>$ small), and either as long- or short-tongued (long > 0.8 folded proboscis length > short).

A total of 487 male euglossine bees from 23 species were captured (Table 1). No marked bees were recaptured. Most individuals were captured at the farmlands $(63.45 \%)$, followed by the highly disturbed forest $(26.90 \%)$, and the least at the less disturbed forest $(9.65 \%)$. The number of captured species were 15, 18 and 9, at each habitat, respectively. A low correlation between captured numbers of individuals and species was found from the 12 sampling sites (Spearman, $R=0.571$ ). The number of captured individuals was significantly different between habitats (KruskalWallis, $\mathrm{H}=9.269$, $\mathrm{df}=2, \mathrm{~N}=12, \mathrm{p}=0.01$ ), as well as the number of species $(\mathrm{H}=6.606, \mathrm{df}=$ $2, \mathrm{~N}=12, \mathrm{p}=0.037)$. The lack of recaptures probably was due to traumatic manipulation, generating avoidance to traps, or because of large population sizes.

Six of the 23 species account for $86.24 \%$ of the total individuals captured (see marked species in Table 1). Three Eulaema spp., are big-bodied species, and all except Euglossa hansoni, are long-tongued. Capture abundances between habitats were not significantly different for two of these species, which together amounted for $18.18 \%$ of the captured individuals: Eg. hansoni $(\mathrm{H}=3.933, \mathrm{p}=$ $0.140)$ and Eglossa imperialis $(\mathrm{H}=2.217, \mathrm{p}=$ 0.330 ). Capture abundances were significantly different for the other four frequently captured species, which together account for $67.7 \%$ of the captured individuals: Eulaema bombiformis $(\mathrm{H}=8.893, \mathrm{p}=0.012)$, Eulaema chocoana $(\mathrm{H}=9.986, \mathrm{p}=0.007)$, Eulaema cingulata $(\mathrm{H}=7.948, \mathrm{p}=0.019)$, and Euglossa ignita $(\mathrm{H}=7.750, \mathrm{p}=0.023)$. These four species were captured more frequently at the farmland rather than at the less disturbed forest. Percentages of the total individuals captured for each of these species at these two habitats, farmland and less disturbed forest, were, respectively: Eulaema bombiformis

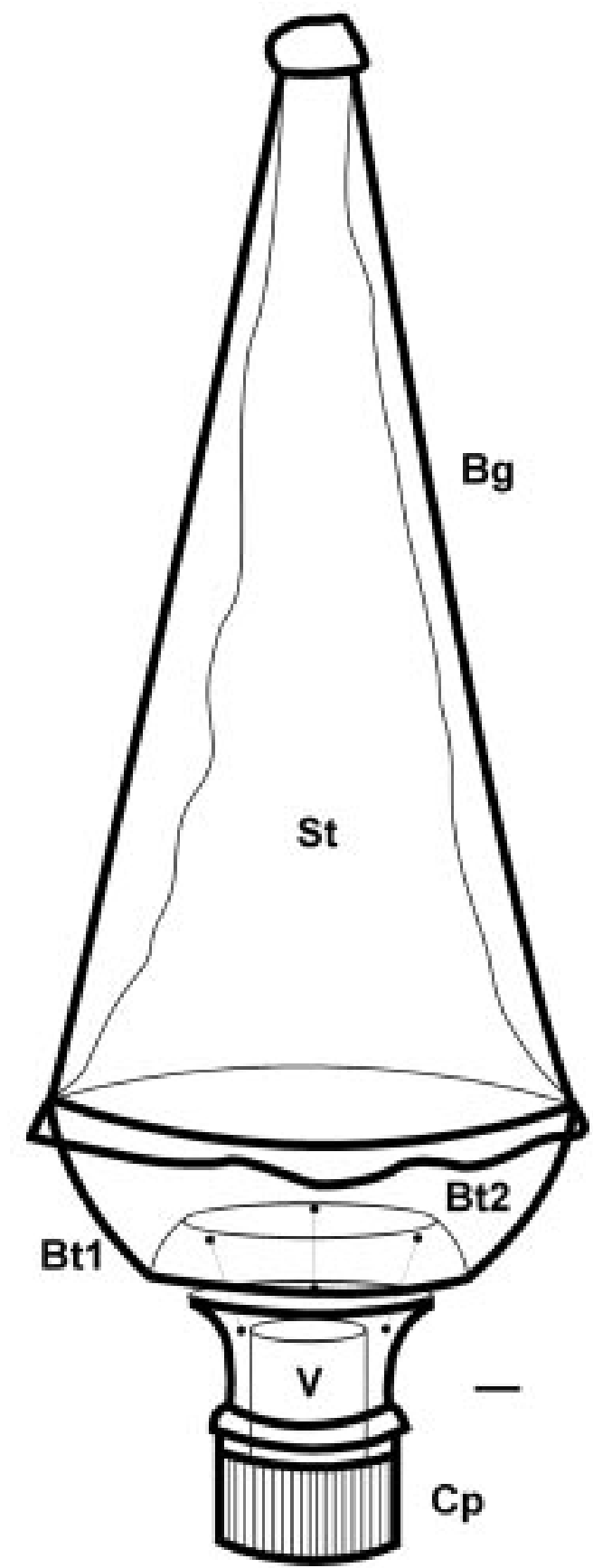

Fig. 1. Non-lethal male euglossine trap. The bottom part is made from the upper part of a 21 disposable plastic bottle, cut in three parts (Bt1, Bt2 and $\mathrm{Cp}$ ) and forming an inverted funnel. The baited vial (V) is inside the hanging cap $(\mathrm{Cp})$. The upper part is made from a white nylon stocking (St) covered with a clear plastic bag (Bg). Scale bar $=1 \mathrm{~cm}$. Upper part not to scale, length $=45 \mathrm{~cm}$. 
TABLE 1

Number of male euglossine bees captured using three chemical baits per site, at three adjacent habitats, ten sampling days (40 hrs) and four sampling sites per habitat

\begin{tabular}{|c|c|c|c|}
\hline Species & Farmland & Logging forest & Less disturbed forest \\
\hline *Eulaema chocoana & 136 & 21 & 1 \\
\hline *El. bombiformis & 25 & 10 & - \\
\hline *El. cingulata & 20 & 1 & 5 \\
\hline El. sororia & - & 1 & - \\
\hline *Euglossa ignita & 87 & 14 & 11 \\
\hline *Eg. imperialis & 6 & 31 & 9 \\
\hline$*$ Eg. hansoni $\mathrm{sh}$ & 5 & 30 & 8 \\
\hline Eg. tridentata ${ }^{\text {sh }}$ & 10 & 2 & - \\
\hline Eg. deceptrix ${ }^{\text {sh }}$ & 4 & 1 & - \\
\hline Eg. dressleri ${ }^{\text {sh }}$ & 2 & 1 & 1 \\
\hline Eg. championi ${ }^{\text {sh }}$ & - & 5 & 3 \\
\hline Eg. townsendi $i^{\text {sh }}$ & 1 & - & - \\
\hline Eg. allosticta & 8 & 2 & - \\
\hline Eg. flammea & - & 4 & - \\
\hline Eg. bursigera & 1 & 3 & - \\
\hline Eg. gorgonensis & 2 & - & 2 \\
\hline Eg. asarophora & - & 2 & - \\
\hline Eg. chalybeata & - & 1 & - \\
\hline Euglossa (Glossurella) sp. 01 & - & 1 & - \\
\hline Euglossa (Glossurella) sp. 09 & 1 & - & - \\
\hline Eufriesea pulchra & 1 & - & \\
\hline Exaerete smaragdina & - & - & 7 \\
\hline Ex. frontalis & - & 1 & - \\
\hline Total individuals & 309 & 131 & 47 \\
\hline Total species & 15 & 18 & 9 \\
\hline
\end{tabular}

* Most frequent species, ${ }^{\text {sh }}$ short tongued species.

$71.43 \%$ and $0 \%$, El. chocoana $86.08 \%$ and $0.63 \%$, El. cingulata $76.92 \%$ and $19 \%$, Eg. ignita $77.68 \%$ and $9.82 \%$. The same traps had been previously used to sample open areas and forest habitats contiguous to each other, but gave higher capture rates at the forests (Sandino 1995), then a presumed higher dispersal of the bait probably does not account for higher capture rates at the farmlands.

A k-means two cluster analysis, of the logtransformed capture data matrix, for the 23 species and 12 sites, placed together the four farmland sites in one group, and the eight forest sites in another. A further three cluster analysis grouped together three highly disturbed forest sites, and the remaining highly disturbed forest site with the four less disturbed forest sites.

In brief, the farmlands provided distinct samples, and more frequent captures of male euglossine bees, particularly of four of the six most frequently captured species. The less disturbed forest gave poor capture rates of these four species, despite the sampling sites were only $2 \mathrm{~km}$ away from the farmlands, an easy and brief distance for an euglossine bee (Janzen 1971, Dressler 1982). It is noteworthy the abundance at the farmlands of the apparently endemic El. chocoana, first identified as a new species from a few individuals collected in a mature forest, at the pacific coast of Colombia (Sandino 1995, Ospina and Sandino 1997). All the other frequently captured species range widely throughout the lowland American tropics.

Since male euglossines seem to be baitsampled abundantly near resource patches (Armbruster 1993), capture frequencies may reflect to some extent habitat use during foraging, though leave unclear how much time 
males spend at each habitat (Roubik 2001). Thus, high capture frequencies at the farmland sites may, at least in part, reflect the use of this habitat during foraging, and this could be related to what is suspected is a clumped, rich and abundant offer of nectar and fragrance resources at farmlands of the kind sampled here. Nonetheless, these farmland resources 1) could be less diversified than those found at less disturbed habitats, favoring generalist species like those with ample geographical distributions, and 2) seems particularly rich in flowers of deep corollas (i.e. Heliconia spp. and Calathea spp. were very common) fitting better long-tongued species, which are more efficient in exploiting nectar resources. Microclimatic conditions may impose further limitations to the euglossine foraging of farmland resources, suiting big sized species which could be better adapted for thermoregulation in the low humidity and high temperatures characteristic of the open areas (Janzen 1974, May and Casey 1983, Roubik 1993).

\section{ACKNOWLEDGMENTS}

Diana Galvis made the trap drawing. AFEPAL and the community of Guaimía provided the sampling permits. The families of Bernardo Angulo and Apolinar Angulo, Jr. kindly assisted every aspect of fieldwork. J. Olander and F. Gast encouraged funding, which was provided by the Proyecto Biopacífico (Colombian Ministry of the Environment/GEF/UNDP).

\section{RESUMEN}

Durante treinta días y en doce sitios de muestreo en la costa pacífica central de Colombia (diez días y cuatro sitios en cada uno de tres hábitats adyacentes: fincas, bosque muy perturbado y bosque menos perturbado), se capturaron 487 machos euglosinos. La mayoría de machos pertenecen a seis especies, cinco de amplia distribución en tierras bajas de la América tropical y una endémica. De es- tas seis especies, dos no presentan diferencias significativas en su distribución entre hábitats, mientras que las otras cuatro (que representan $67.97 \%$ del total de individuos capturados), todas grandes o de lenguas largas, fueron capturadas con mayor frecuencia en las fincas. Un análisis de agrupamiento de la matriz de datos, para las 23 especies capturadas y los 12 sitios de muestreo, agrupó los sitios de finca aparte de los de bosque. Se propone que los machos euglosinos de especies generalistas, grandes o de lenguas largas, forrajearían con mayor frecuencia en las fincas, pues allí los recursos de néctar o fragancias presentarían mayor densidad, menor diversidad o un acceso restringido por corolas profundas o por condiciones microclimáticas de alta temperatura y baja humedad.

\section{REFERENCES}

Armbruster, W.S. 1993. Within-habitat heterogeneity in baiting samples of male euglossine bees: possible causes and implications. Biotropica 25: 122-128.

Dressler, R.L. 1982. Biology of the orchid bees (Euglossini). Ann. Rev. Ecol. Syst. 13: 373-394.

Janzen, D.H. 1971. Euglossine bees as lond-distance pollinators of tropical plants. Science 171: 203-205.

Janzen, D.H. 1974. The deflowering of Central America. Nat. Hist. 83: 48-53.

Kimsey, L.S. 1982. Systematics of the bees of the genus Eufriesea. Univ. Calif. Publ. Entomol. Vol. 95

May, M.L. \& T.M. Casey. 1983. Thermorregulation and heat exchange in euglossine bees. Physiol. Zool. 56: 541-551.

Ospina, R. \& J.C. Sandino. 1997. Eulaema chocoana, new euglossine bee species from the Pacific coast of Colombia. Caldasia 19: 165-174

Roubik, D.W. 1993. Tropical pollinators in the canopy and understory: field data and theory for stratum "preferences". J. Insect Behav. 6: 659-674.

Roubik, D.W. 2001. Ups and downs in pollinator populations: When is there a decline? Conserv. Ecol. 5(1): 2. (Also available online http://www.consecol.org/vol5/iss1/art2).

Sandino, J.C. 1995. Primer inventario de abejas euglosinas en la vertiente del Pacífico del suroccidente de Colombia: diversidad, distribución altitudinal y efectos de la perturbación humana. Tesis de pregrado, Universidad del Valle, Cali, Colombia. 